\title{
US Government and American Muslims Engage to Define Islamophobia
}

On 4 December 2006, the American Muslims' national leadership met with key senior American government officials to discuss Islamophobia in the country and American-Muslim relations. The conference, organized by the Bridging the Divide Initiative of the Saban Center at the Brookings Institution, was co-sponsored by the Institute for Social Policy and Understanding (ISPU) and the Association of Muslim Social Scientists (AMSS).

As conference chair, I had to bring together two parties that did not see eye-to-eye on this issue. While American Muslim leaders and participants argued that Islamophobia was not only a reality but also a rapidly growing phenomenon in the United States, the government's position was that while there have been increased incidences of anti-Muslim episodes in the country, the word Islamophobia deepens the divide between the two sides. Other 
government representatives also suggested that the fear to which Muslims were referring was not that of Islam, but rather that of Muslim terrorism, as manifested on 11 September 2001.

Stephen Grand (director, United States-Islamic World program) welcomed all participants and launched the conference. The government was represented by the Department of State, the Department of Homeland Security, and associated agencies. The morning keynote address was delivered by Alina Romanowski (Deputy Assistant Secretary of State for Professional and Cultural Affairs). She was introduced by Ambassador Martin Indyk (director, the Saban Center), who proclaimed the importance of such dialogues at a time when the gap between the United States and the Muslim world appears to be widening.

Romanowski reiterated the vision and objectives that Ambassador Karen Hughes seeks to advance at the State Department on public diplomacy. She talked about the three key public diplomacy objectives: offering a positive vision of hope and opportunity around the world that is rooted in the United States' belief in freedom, justice, opportunity, and respect for all; isolating and marginalizing violent extremists and confronting their ideology of hate and tyranny; and fostering a sense of the common values and common interests between Americans and peoples of different countries, cultures, and faiths. The question-and-answer session was remarkably open and candid. Romanowski agreed to relay the issues raised to others in the State Department. Listening and creating opportunities for people-to-people exchanges and dialogue, she said, was a key component of the work of the Department of State's Education and Cultural Affairs Bureau.

Farid Senzai (fellow and director of research, ISPU) chaired the panel on "The Rise of Islamophobia and Anti-Muslim Hate Crimes." Nihad Awad (executive director, Council on American Islamic Relations [CAIR]) argued that Islamophobia was a new word but not a new phenomenon. His data indicated that such hate crimes rose by 29 percent in the last year. Since 1995, when CAIR started collecting such data, the figures have increased steadily. He concluded that criticizing Islam and Muslims is not Islamophobia, but that ridiculing the faith and the faithful certainly is. Louay Safi (executive director, Islamic Society of North America's Leadership Development Center) insisted that Islamophobia deepens the divide between the United States and the Muslim world. He claimed that Islam is increasingly being presented as a violent and intolerant religion and that this message is spreading from the margins to the mainstream. His "Blaming Islam" report, which was published by ISPU, was released at the event. Imam Mahdi Bray (executive director, Muslim American Society's Freedom Foundation) men- 
tioned his concern that although most Muslims cherish American values, they are portrayed as seditious. He lamented the ignorance of Islam underpinning Islamophobia and suggested that, occasionally, some measures of the government, such as when in its overzealous prosecution of the "war on terror" causes it to overplay its hand and undercut the Muslims' civil rights, may also contribute to the rising number of cases.

The afternoon keynote address was delivered by Dan Sutherland, (officer for civil rights, Department of Homeland Security). He started by observing that there is "a lot of heat but very little light" on Islamophobia. He addressed the issue, as well as the rising number of hate crimes and antiMuslim discourse in the United States, head-on. He argued, based on fifty years of statistical data, that the country has progressively become less racist. Sutherland then spoke at length about the stunning achievements of American Muslims in every sphere of American life, asserting that the degree to which they are integrated and successful belies any claims of systematic Islamophobia. After conceding that there have been several Islamophobic episodes, he claimed that many of these incidents were resolved in the Muslims' favor and discussed a few cases where the government has interfered effectively on their behalf. The government's case was very clear: Yes, there is a disturbingly large number of incidents that suggest that prejudice is at work; however, the overall picture indicates that things are not as bad as some Muslim leaders claim.

The final panel of the day included Ahmed Younis (national director, Muslim Public Affairs Council), Imad-ad-Dean Ahmad (AMSS), and Muqtedar Khan (non-resident senior fellow, Brookings Institution; and assistant professor, University of Delaware). This panel sought to balance the debate by arguing that while there are disturbing indications of a growing antiMuslim prejudice in the country, as several surveys reveal, American Muslims must be careful of how they talk about Islamophobia. The panelists also said that American Muslims must work with the government not only to challenge the spreading anti-Islamic discourse here, but also to correct misunderstandings that the government may harbor about Islam and American Muslims. An additional theme was the need to deal with the spreading antiAmericanism within the American Muslim community. Recognizing that anti-Americanism and Islamophobia feed each other, the panelists called for addressing both prejudices simultaneously.

While this was the first such conference on Islamophobia, more interaction between the two parties will be needed to help define the term and reach a common understanding about the extent of anti-Muslim prejudice in this country and how Washington and the community can address it jointly. 
The entire report is available online at www.brookings.edu/views/op$\mathrm{ed} / \mathrm{khan} / 20061219 . \mathrm{htm}$.

M. A. Muqtedar Khan Assistant Professor, Department of Political Science, The University of Delaware Senior Nonresident Fellow, The Saban Center, the Brookings Institution Washington, DC 